\title{
Faktor-Faktor yang Mempengaruhi Pola Asuh Orang Tua pada Anak Balita di Desa Batoh Kecamatan Lueng Bata Kota Banda Aceh
}

\author{
Factors Affecting The Parenting Children Parents of Children in The Village \\ Batoh City Lueng Bata Banda Aceh
}

\author{
Mutia Sari ${ }^{* 1,}$ Nuzulul Rahmi \\ ${ }^{1,2}$ Prodi D-III Kebidanan, Universitas Ubudiyah Indonesia, Banda Aceh, Indonesia \\ *Korespondensi Penulis : nuzululrahmi@uui.ac.id
}

\begin{abstract}
Abstrak
Pola asuh adalah pola prilaku yang digunakan orang tua untuk berhubungan dengan anakanak. Pola asuh yang salah bisa menyebabkan gizi buruk. Seorang anak balita mengalami gizi buruk dapat disebabkan oleh kurang makanan dari Kantor Desa Batoh Kecamatan Lueng Bata Kota Banda Aceh terdapat 453 ibu yang mempunyai anak balita 1- 5 tahun, 325 orang diantaranya ibu yang mempunyai anak balita 2-5 tahun, dan 128 orang lainnya mempunyai anak balita berumur 0-23 bulan. Penelitian ini bersifat Analitik dengan pendekatan Cross sectional. Penelitian ini dilakukan pada tanggal 30 April s/d 15 Mei 2016 dengan Populasi seluruh ibu yang memiliki anak Balita usia 1- 5 tahun sebanyak 453 ibu yang terdapat 4 Dusun dalam wilayah Batoh Kecamatan Lueng Bata Kota Banda Aceh 2016. Pengambilan sampel menggunakan purposive sampling dengan jumlah sampel 82 orang, Pengumpulan data dilakukan dengan menyebarkan kuesioner. Kemudian di uji statistik mengunakan Chi-quare. Hasil penelitian bahwa yang berpendidikan tinggi yang setuju dengan pola asuh dialogis sebesar 78,3\%, $\mathrm{p}$ value $=0,024$, berpengetahuan tinggi yang setuju dengan pola asuh dialogis sebesar $80,6 \%$ p value $=0,002$, ibu yang pendapatan keluarga yang sesuai UMP yang setuju dengan pola asuh dialogis sebesar 78,8\% p value $=0,003$, status gizi balitanya kurus yang setuju dengan pola asuh dialogis sebesar $80,0 \%$ dan ibu yang status gizi anak balitanya gemuk $p$ value $=0,022$. Ada pengaruh pendidikan, pengetahuan, pendapatan, dan status gizi Terhadap Pola Asuh Orang Tua Pada Anak Balita Di Desa. Diharapkan Bagi masyarakat di tempat penelitian, sebagai tambahan informasi tentang faktor-faktor yang mempengaruhi pola asuh orang tua pada anak balita di Desa Batoh Lueng Bata Kota Banda Aceh Tahun 2016.
\end{abstract}

Kata Kunci: Pola Asuh Orang Tua Pada Anak Balita

\begin{abstract}
Parenting is a behavior pattern that is used to connect parents with children. The wrong upbringing can lead to malnutrition. A child under five suffering from severe malnutrition can be caused by lack of food. from the Office of the District Batoh Lueng Bata village of Banda Aceh there were 453 mothers with young children 1 to 5 years, 325 of them mothers with young children 2-5 years old, and 128 others have young children aged 0-23 monthsObjective: To determine the factors that affect parenting parents of children under five with in the District Batoh Lueng Bata village of Banda Aceh 2016. This research is an analytic approach cectional Cross. The population of all mothers with children under five years of age 1- 54534 Dusun mothers contained in the District Batoh Lueng Bata region of
\end{abstract}


Banda Aceh, 2016.The sampling using purposiv sampling with a sample of 82 people. This research was conducted in 30 April s/d 15 May 2016. Data was collected by distributing questionnaires. Later in using statistical test Chi-quare. The results that the highly educated who agree with parenting Dialogic is $78.3 \%$, $p$ value $=0.024$, knowledgeable high agree with parenting Dialogic $80.6 \%$ p value $=0.002$, mothers appropriate family income UMP agree with parenting dialogic by $78.8 \%$ p value $=0.003$, the nutritional status of children under five underweight agreed with parenting dialogic by $80.0 \%$ and maternal nutritional status chubby toddler $p$ value $=0.022$. There is a influence between education, knowledge, income, and statu nutrition Against Parenting Parents On Childhood In the village Advice: Expected For the people in the study, as additional information about the factors that affect parenting parents of children under five in the village Batoh Lueng Bata Banda Aceh 2016.

Keywords: Parenting Parents On Childhood

\section{PENDAHULUAN}

Pengasuhan anak didefinisikan sebagai perilaku yang diperhatikan oleh pengasuh (ibu, bapak, nenek, atau orang lain) dalam memberikan makanan, pemeliharaan kesehatan, memberikan stimulasi, kasih sayang dan tanggung jawab orang tua serta dukungan emosional yang dibutuhkan anak untuk tumbuh kembang (Anwar, 2008)

Pola asuh adalah pola prilaku yang digunakan orang tua untuk berhubungan dengan anak-anak. Pola asuh yang salah bisa menyebabkan gizi buruk. Seorang anak balita mengalami gizi buruk dapat disebabkan oleh kurang makanan. Pola asuh yang salah maupun karena faktor genetis. Gizi buruk akibat kurang makan biasanya terjadi pada keluarga miskin, sedangkan pola asuh yang salah terjadi pada keluarga mampu yang kurang memperhatikan keseimbangan gizi makanan anaknya (Amal, 2010).

Banyak faktor yang mempengaruhi pola asuh balita diantaranya adalah pendidikan, pengetahuan, pendapatan dan status gizi. Seseorang yang berpendidkan tinggi diyakini mempunyai pengetahuan yang baik sehingga lebih mengerti bagaimana mengasuh anak, demikian sebaliknya. Dari aspek pendapatan dijelaskan pada keluarga yang mempunyai pendapatan tinggi cenderung lebih memanjakan anaknya dengan berbagai fasilitas, hal ini berbeda jauh dengan pengasuhan yang diterapkan oleh keluarga dengan pendapatan rendah (Anwar, 2008).

Sering dikatakan bahwa ibu adalah jantung dari keluarga, jantung dalam tubuh merupakan alat yang sangat penting bagi kehidupan seseorang.Apabila jantung berhenti berdenyut maka orang itu tidak bisa melangsungkan hidupnya.Dari perumpaan ini bisa disimpulkan bahwa kedudukan seorang ibu sebagai tokoh sentral dan sangat penting untuk 
melaksanakan kehidupan.Pentingnya seorang ibu terutama terlihat sejak kelahiran anaknya (Gunarsa, 2007).

Agar pola hidup anak bisa sesuai dengan standar kesehatan, disamping harus mengatur pola makan yang benar juga tak kalah pentingnya mengatur pola asuh yang benar pula.Pola asuh yang benar bisa ditempuh dengan memberikan perhatian yang penuh serta kasih sayang pada anak, memberinya waktu yang cukup untuk menikmati kebersamaan dengan seluruh anggota keluarga.Dalam masa pengasuhan, lingkungan pertama yang berhubungan dengan anak adalah orang tuanya.Anak tumbuh dan berkembang di bawah asuhan dan perawatan orang tua oleh karena itu orang tua merupakan dasar pertama bagi pembentukan pribadi anak.Melalui orang tua, anak beradaptasi dengan lingkungannya untuk mengenal dunia sekitarnya serta pola pergaulan hidup yang berlaku dilingkungannya. Dengan demikian dasar pengembangan dari seorang individu telah diletakkan oleh orang tua melalui praktek pengasuhan anak sejak ia masih bayi (Supanto, 2009).

Dalam mengenalkan kedisiplinan pada anak, dikenal adanya metode V yaitu metode yang lebih banyak menerapkan kebiasaan pada usia dini. Kemudian ketika anak memasuki usia remaja, anak diberi keleluasan dalam memilih dan berprilaku. Kebiasaan yang sering temui adalah kebalikannya, yaitu permisif di usia dini, dan dialogis di usia remaja. Pendenkatan ini memiliki dua kelemahan. Pertama, permisif di usia dini mengakibatkan anak tidak mengenal kebiasaan/ habitat yang baik. Memang seringkali orang tua beranggapan anak nya belum siap menerima suatu pengajaran kebiasaan. Padahal justru dimasa ini inilah orang tua bisa memperkenalkan kebiasaan yang baik karena anak masih lebih mudah menerima perubahan. Pendekatan yang baik adalah mengenalkan kebiasaan-kebiasaan yang di ingankan diusia dini. Misalnya : makan dengan tangan kanan, berjabat tangan, mandi di pagi dan sore hari, tidur pada waktunya, dan lain-lain. Menginjak usia yang yang memungkinkan anak memiliki pilihan sendiri, orang tuan berperan sebagai teman (Amal, 2007).

Berdasarkan data yang diperoleh dari Kantor Desa Batoh Kecamatan Lueng Bata Kota Banda Aceh terdapat 453 ibu yang mempunyai anak balita 1- 5 tahun, 325 orang diantaranya ibu yang mempunyai anak balita 2-5 tahun, dan 128 orang lainnya mempunyai anak balita berumur 0-23 bulan.

Berdasarkan latar belakang di atas, maka peneliti tertarik untuk melakukan penelitian yang berjudul "Faktor- Faktor Yang Mempengaruhi Pola Asuh Orang Tua Pada Anak Balita di Desa Batoh Kecamatan Lueng Bata Kota Banda Aceh Tahun 2016”. 


\section{METODE PENELITIAN}

Jenis penelitian yang digunakan adalah penelitian deskriptif dengan pendekatan crosssectional.(Notoatmodjo,2005). Yaitu dengan Faktor-faktor yang mempengaruhi pola asuh orang tua pada anak balita di desa batoh kecamatan Lueng bata kota Banda Aceh. Tempat penelitian ini dilakukan di Desa Batoh Kecamatan Lueng Bata Kota Banda Aceh waktu pembagian kuesioner dimulai pada tanggal 30 April s/d 15 Mei 2016. Populasi dalam penelitian ini yaitu ibu yang memiliki anak Balita usia 1- 5 tahun sebanyak 453 ibu yang terdapat 4 Dusun dalam wilayah Batoh Kecamatan Lueng Bata Kota Banda Aceh 2016. Sampel yang ditetapkan pada penelitian ini adalah 82 orang ibu yang memiliki anak balita usia 1-5 tahun .

\section{HASIL PENELITIAN}

Tabel 1. Distribusi Frekuensi Pola Asuh Orang Tua Pada Anak Balita di Desa Batoh Kecamatan Lueng Bata Kota Banda AcehTahun 2016

\begin{tabular}{clcc}
\hline No & Pola Asuh Orang Tua Pada Anak & Frekuensi & Persentase \\
Balita & Pola Asuh Dialogis & 47 & $57,342,7$ \\
\hline 1 & Pola Asuh Koersif & 35 & \\
\hline \multicolumn{2}{c}{ Total } & $\mathbf{8 2}$ & $\mathbf{1 0 0}$ \\
\hline
\end{tabular}

Berdasarkan tabel 1 dapat menunjukkan bahwa dari 82 responden mayoritas berada pada kategori memiliki pola asuh orang tua pada anak balita yang pola asuh dialogis yaitu sebanyak 47 responden $(57,3 \%)$.

Tabel 2. Distribusi Frekuensi Pendidikan Ibu di Desa Batoh Kecamatan Lueng Bata Kota Banda Aceh Tahun 2016

\begin{tabular}{|c|c|c|c|}
\hline No & Pendidikan Ibu & Frekuensi & Persentase \\
\hline 1 & Tinggi & 23 & 28,0 \\
\hline 2 & Menengah & 19 & 23,2 \\
\hline 3 & Dasar & 40 & 48,8 \\
\hline & Total & 82 & 100 \\
\hline
\end{tabular}

Berdasarkan tabel 2 dapat menunjukkan bahwa dari 82 responden mayoritas berada pada kategori pendidikan dasar yaitu sebanyak 40 responden $(48,8 \%)$. 
Tabel 3. Distribusi Frekuensi Pengetahuan Ibu di Desa Batoh Kecamatan Lueng Bata Kota Banda Aceh Tahun 2016

\begin{tabular}{|c|c|c|c|}
\hline No & Pengetahuan Ibu & Frekuensi & Persentase \\
\hline 1 & Tinggi & 31 & 37,8 \\
\hline 2 & Sedang & 51 & 62,2 \\
\hline & Total & 82 & 100 \\
\hline
\end{tabular}

Berdasarkan tabel 3 dapat menunjukkan bahwa dari 82 responden mayoritas berada pada kategori memiliki pengetahuan sedang yaitu sebanyak 51 responden $(62,2 \%)$.

Tabel 4. Distribusi Frekuensi Pendapatan Keluarga di Desa Batoh Kecamatan Lueng Bata Kota Banda Aceh Tahun 2016

\begin{tabular}{llcc}
\hline No & Pendapatan Keluarga & Frekuensi & Persentase \\
\hline 1 & Sesuai UMP & 33 & 40,2 \\
2 & Tidak Sesuai UMP & 49 & 59,8 \\
\hline & Total & $\mathbf{8 2}$ & $\mathbf{1 0 0}$ \\
\hline
\end{tabular}

Berdasarkan tabel 4 dapat menunjukkan bahwa dari 82 responden mayoritas berada pada kategori memiliki pendapatan keluarga tidak sesuai UMP yaitu sebanyak 49 responden $(59,8 \%)$.

Tabel 5. Distribusi Frekuensi Status Gizi Balita di Desa Batoh Kecamatan Lueng Bata Kota Banda Aceh Tahun 2016

\begin{tabular}{llcc}
\hline No & Status Gizi & Frekuensi & Persentase \\
\hline 1 & Gemuk & 14 & 17,1 \\
2 & Normal & 43 & 52,4 \\
3 & Kurus & 25 & 30,5 \\
\hline & Total & $\mathbf{8 2}$ & $\mathbf{1 0 0}$ \\
\hline
\end{tabular}

Berdasarkan tabel 5 dapat menunjukkan bahwa dari 82 responden mayoritas berada pada kategori memiliki status gizi normal yaitu sebanyak 43 responden $(52,4 \%)$. 
Tabel 6. Pengaruh Pendidikan Ibu Terhadap Pola Asuh Orang Tua Pada Anak Balita di Desa Batoh Kecamatan Lueng Bata Kota Banda Aceh Tahun 2016

\begin{tabular}{|c|c|c|c|c|c|c|c|c|}
\hline \multirow{3}{*}{ No } & \multirow{3}{*}{ Pendidikan Ibu } & \multicolumn{4}{|c|}{$\begin{array}{c}\text { Pola Asuh Orang Tua } \\
\text { Pada Anak Balita } \\
\end{array}$} & \multirow{2}{*}{\multicolumn{2}{|c|}{ Total }} & \multirow{3}{*}{$\begin{array}{c}\text { P- } \\
\text { value }\end{array}$} \\
\hline & & \multicolumn{2}{|c|}{$\begin{array}{l}\text { Pola Asuh } \\
\text { Dialogis }\end{array}$} & \multicolumn{2}{|c|}{$\begin{array}{l}\text { Pola Asuh } \\
\text { Koersif }\end{array}$} & & & \\
\hline & & $\mathbf{f}$ & $\%$ & $\mathbf{f}$ & $\%$ & $\mathbf{f}$ & $\%$ & \\
\hline 1 & Tinggi & 18 & 78,3 & 5 & 21,7 & 23 & 100 & \\
\hline 2 & Menengah & 7 & 36,8 & 12 & 63,2 & 19 & 100 & 0,024 \\
\hline 3 & Dasar & 22 & 55 & 18 & 45,0 & 40 & 100 & \\
\hline
\end{tabular}

Berdasarkan tabel 6 dapat dilihat bahwa dari 23 responden ibu yang berpendidikan tinggi melakukan pola asuh secara dialogis sebesar 78,3\%. dari 40 responden ibu yang berpendidikan dasar melakukan pola asuh secaradialogis sebesar 55\%. dari 19 responden ibu yang berpendidikan menengah melakukan pola asuh secara dialogissebesar 36,8\%.

Hasil analisis statistik menggunakan uji chi-square didapatkan $\mathrm{p}$ value $=0,024$. Sehingga dapat disimpulkan bahwa $\mathrm{p}<0,05$ yang artinya $\mathrm{Ha}$ diterima atau terdapat pengaruh pendidikan ibu terhadap pola asuh orang tua pada anak balita di Desa Batoh Kecamatan Lueng BataKota Banda Aceh Tahun 2016.

Tabel 7. Pengaruh Pengetahuan Ibu Terhadap Pola Asuh Orang Tua Pada Anak Balita Di Desa Batoh Kecamatan Lueng Bata Kota Banda Aceh Tahun 2016

\begin{tabular}{|c|c|c|c|c|c|c|c|c|}
\hline \multirow{3}{*}{ No } & \multirow{3}{*}{ Pengetahuan } & \multicolumn{4}{|c|}{$\begin{array}{l}\text { Pola Asuh Orang Tua } \\
\text { Pada Anak Balita }\end{array}$} & \multirow{2}{*}{\multicolumn{2}{|c|}{ Total }} & \multirow[t]{2}{*}{ P-value } \\
\hline & & \multicolumn{2}{|c|}{$\begin{array}{c}\text { Pola Asuh } \\
\text { Dialogis }\end{array}$} & \multicolumn{2}{|c|}{$\begin{array}{c}\text { Pola Asuh } \\
\text { Koersif }\end{array}$} & & & \\
\hline & & f & $\%$ & $\mathbf{f}$ & $\%$ & $\mathbf{F}$ & $\%$ & \\
\hline 1 & Tinggi & 25 & 80,6 & 6 & 19,4 & 31 & 100 & 0,002 \\
\hline 2 & Sedang & 22 & 43,1 & 29 & 56,9 & 51 & 100 & \\
\hline
\end{tabular}

Berdasarkan tabel 7 dapat dilihat bahwa dari 31 responden ibuyang berpengetahuan tinggi melakukan pola asuh dialogis sebesar 80,6\%. Dari 51 respondenibu yang berpengetahuan sedang melakukan pola asuh dialogis sebesar $43,1 \%$.

Hasil analisis statistik menggunakan uji chi-square didapatkan p value $=0,002$. Sehingga dapat disimpulkan bahwa $\mathrm{p}<0,05$ yang artinya Ha diterima atau terdapat pengaruh 
pengetahuan ibu terhadap pola asuh orang tua pada anak balita di Desa Batoh Kecamatan Lueng BataKota Banda Aceh Tahun 2016.

Tabel 8. Pengaruh Pendapatan Keluarga Terhadap Pola Asuh Orang Tua Pada Anak Balita Di Desa Batoh Kecamatan Lueng Bata Kota Banda Aceh Tahun 2016

\begin{tabular}{|c|c|c|c|c|c|c|c|c|}
\hline \multirow{3}{*}{ No } & \multirow{3}{*}{$\begin{array}{l}\text { Pendapatan } \\
\text { Keluarga }\end{array}$} & \multicolumn{4}{|c|}{$\begin{array}{l}\text { Pola Asuh Orang Tua } \\
\text { Pada Anak Balita }\end{array}$} & \multirow{2}{*}{\multicolumn{2}{|c|}{ Total }} & \multirow{3}{*}{ P-value } \\
\hline & & \multicolumn{2}{|c|}{$\begin{array}{l}\text { Pola Asuh } \\
\text { Dialogis }\end{array}$} & \multicolumn{2}{|c|}{$\begin{array}{c}\text { Pola Asuh } \\
\text { Koersif }\end{array}$} & & & \\
\hline & & $\mathbf{f}$ & $\%$ & $\mathbf{f}$ & $\%$ & $\mathbf{f}$ & $\%$ & \\
\hline 1 & Sesuai UMP & 26 & 78,8 & 7 & 21,2 & 33 & 100 & \\
\hline 2 & $\begin{array}{ll}\text { Tidak } & \text { Sesuai } \\
\text { UMP } & \end{array}$ & 21 & 42,9 & 28 & 57,1 & 49 & 100 & 0,003 \\
\hline
\end{tabular}

Berdasarkan tabel 8 dapat dilihat bahwa dari 33 responden ibu yang pendapatan keluarga yang sesuai UMP melakukan pola asuh dialogis sebesar 78,8\%. Dari 49 responden ibu yang berpendapatan keluarga yang tidak sesuai dengan UMP melakukan pola asuh dialogis sebesar $42,9 \%$.

Hasil analisis statistik menggunakan uji chi-square didapatkan $\mathrm{p}$ value $=0,003$. Sehingga dapat disimpulkan bahwa $\mathrm{p}<0,05$ yang artinya $\mathrm{Ha}$ diterima atau terdapat pengaruh pendapatan keluarga terhadap pola asuh orang tua pada anak balita di Desa Batoh Kecamatan Lueng BataKota Banda Aceh Tahun 2016.

Tabel 9. Pengaruh Status Gizi Terhadap Pola Asuh Orang Tua Pada Anak Balita Di Desa Batoh Kecamatan Lueng Bata Kota Banda Aceh Tahun 2016

\begin{tabular}{|c|c|c|c|c|c|c|c|c|}
\hline \multirow{3}{*}{ No } & \multirow{3}{*}{ Status Gizi } & \multicolumn{4}{|c|}{$\begin{array}{l}\text { Pola Asuh Orang Tua } \\
\text { Pada Anak Balita }\end{array}$} & \multirow{2}{*}{\multicolumn{2}{|c|}{ Total }} & \multirow[t]{2}{*}{ P-value } \\
\hline & & $\begin{array}{l}\text { Pola } \\
\text { Dialogis }\end{array}$ & Asuh & $\begin{array}{l}\text { Pola } \\
\text { Koersif }\end{array}$ & Asuh & & & \\
\hline & & f & $\%$ & f & $\%$ & f & $\%$ & \\
\hline 1 & Gemuk & 7 & 50,0 & 7 & 50,0 & 14 & 100 & \\
\hline 2 & Normal & 20 & 46,5 & 23 & 53,5 & 43 & 100 & 0,022 \\
\hline 3 & Kurus & 20 & 80,0 & 5 & 20,0 & 25 & 100 & \\
\hline
\end{tabular}

Berdasarkan tabel 9 dapat dilihat bahwa dari 25 responden ibu yang status gizi balitanya kurus melakukan pola asuh dialogis sebesar 80,0\% dari 14 responden ibu yang status gizi anak balitanya gemuk melakukan pola asuh dialogis sebesar 50,0\%. Dari 43 
responden ibu yang status gizi anak balitanya normal melalukan pola asuh dialogis sebesar 46,5\%. Hasil analisis statistik menggunakan uji chi-square didapatkan $\mathrm{p}$ value $=0,022$. Sehingga dapat disimpulkan bahwa $\mathrm{p}<0,05$ yang artinya Ha diterima atau terdapat pengaruh status gizi terhadap pola asuh orang tua pada anak balita di Desa Batoh Kecamatan Lueng Bata Kota Banda Aceh Tahun 2016.

\section{Pembahasan}

1. Pengaruh Pendidikan Ibu Terhadap Pola Asuh Orang Tua Pada Anak Balita Di Desa

Berdasarkan hasil penelitian yang telah dilakukan oleh peneliti menunjukkan bahwa dari 23 responden ibu yang berpendidikan tinggi melakukan pola asuh dialogis sebesar 78,3\%. Dari 40 responden ibu yang berpendidikan dasar melakukan pola asuh dialogis sebesar 55\%. Dari 19 responden ibu yang berpendidikan menengah melakukan pola asuh dialogis sebesar $36,8 \%$.

Hasil analisis statistik menggunakan uji chi-square didapatkan $\mathrm{p}$ value $=0,024$. Sehingga dapat disimpulkan bahwa $\mathrm{p}<0,05$ yang artinya Ha diterima atau terdapat pengaruh pendidikan ibu terhadap pola asuh orang tua pada anak balita di Desa Batoh Kecamatan Lueng BataKota Banda Aceh Tahun 2016.

Hasil penelitian ini sama dengan penelitian yang dilakukan oleh Rosdiana,(2009) yang berjudul "Faktor-Faktor Yang Mempengaruhi Pola Asuh Anak Balita di Posyandu Gampong Panjo Kecamatan Kembang Tanjong Kabupaten Pidie”. dari 20 responden dengan pendidikan tinggi dengan polaasuhyang otoriterdi terdapat9balita(22\%).Dari hasil uji statistik didapat $\mathrm{p}$-value $=0,001$ yang artinya $\mathrm{Ha}$ diterima atau terdapat pengaruh pendidikan ibu terhadap pola asuh orang tua pada anak balita.

Hasil penelitian ini sama dengan penelitian yang dilakukan oleh Kharmina,(2009) yang berjudul "Hubungan Antara Tingkat Pendidikan Orang Tua Dengan Orientasi Pola Asuh Anak Usia Dini ".dari 30 responden dengan pendidikan tinggi dengan polaasuhyang permisif sebanyak 15 (50\%). Dari hasil uji statistik didapat $p$-value $=0,011$ yang artinya Ha diterima atau terdapat pengaruh pendidikan ibu terhadap pola asuh orang tua pada anak usia dini.

Hasil penelitian ini sama dengan penelitian yang dilakukan oleh Dwi, (2009) yang Analisis Tingkat Pendidikan Dan Pola Asuh Orang Tua Dengan Perkembangan Anak Usia 48-60 Bulan" dari 40 responden yang berpendidikan tinggi 30 responden (75\%) Dan Pola 
Asuh Orang Tua permisif, Dari hasil uji statistik didapat $\mathrm{p}$-value= 0,009 yang artinya Ha diterima atau terdapat pengaruh pendidikan ibu terhadap pola asuh orang tua pada anak dengan Perkembangan Anak Usia 48-60 Bulan.

Menurut Notoatmodjo, (2007) pendidikan dalam arti formal sebenarnya adalah suatu proses penyampaian bahan-bahan/ materi pendidikan kepada sasaran pendidikan (anak didik) guna mencapai perubahan tingkah laku/ tujuan. Pendidikan bertalian dengan transmisi pengetahuan, sikap, kepercayaan, keterampilan, dan aspek- aspek kelakuan lainnya. Setiap individu pada umumnya menginginkan pendidikan, makin banyak dan makin tinggi pendidikan seseorang maka makin baik tingkat pengetahuan yang dimilikinya.

Menurut kamus besar bahasa indonesia pendidikan adalah jenjang sekolah yang pernah diikuti oleh seseorang, dimana jenjang tersebut telah diatur menurut umur oleh dinas terkait dalam hal ini adalah dinas pendidikan nasional. Jenjang pendidikan yang telah diperbaharui sekarang ini adalah jenjang pendidikan dasar dari tidak sekolah, sekolah dasar sampai dengan sekolah lanjutan pertama, jenjang pendidikan menengah yaitu sekolah menengah atas sederajat serta jenjang pendidikan tinggi meliputi perguruan tinggi yang sederajat (Badudu, 2008).

Peneliti berasumsi bahwapendidikan sangat mempengaruhi pola asuh dialogis karena, ibu di desa batoh yang berpendidikan tinggi sumbangan efektifnya yaitu 78,3\%. pendidikan merupakan hal yang sangat dibutuhkan oleh setiap individu. Semakin tinggi pendidikan seseorang, maka akan semakin terbuka pemikirannya sehingga akan dapat membedakan hal yang benar adanya dan yang diragukan.

\section{Pengaruh Pengetahuan Ibu Terhadap Pola Asuh Orang Tua Pada Anak Balita}

Berdasarkan hasil penelitian yang telah dilakukan oleh peneliti bahwa dari 31 responden ibu yang berpengetahuan tinggi melakukan pola asuh dialogis sebesar 80,6\%. Dari 51 responden ibu yang berpengetahuan sedang melakukan pola asuh dialogis sebesar $43,1 \%$.

Hasil analisis statistik menggunakan uji chi-square didapatkan $\mathrm{p}$ value $=0,002$. Sehingga dapat disimpulkan bahwa $\mathrm{p}<0,05$ yang artinya Ha diterima atau terdapat pengaruh pengetahuan ibu terhadap pola asuh orang tua pada anak balita di Desa Batoh Kecamatan Lueng BataKota Banda Aceh Tahun 2016. 
Hasil penelitian ini sama dengan penelitian yang dilakukan oleh Titih, (2009) yang berjudul "Hubungan Pengetahuan Pola Asuh Anak- Anak Sekolah Taman Kanak- Kanak di Kecamatan Salaman Kabupaten Mangelang Provinsi Jawa” pola asuh ibu pada kategori cukup yaitu sebanyak 16 ibu (51,6\%), dimana pola asuh merupakan interaksi awal yang berguna untuk mengenalkan anak pada aturan atau norma dan tata nilai yang berlaku pada masyarakat disekitar anak dari hasil uji statistik didapat $\mathrm{P}$ - value $=0,023$ yang artinya $\mathrm{Ha}$ diterima atau terdapat pengetahuan terhadap pola asuh orang tua pada anak kanak- kanak.

Hasil penelitian ini sama dengan penelitian yang dilakukan oleh Kharmina,(2009) yang berjudul "Hubungan Antara Tingkat Pendidikan Orang Tua Dengan Orientasi Pola Asuh Anak Usia Dini”dari 100 responden yang berpengetahuan baik yaitu sebanyak 45 (65\%) dengan pola asuh permisif, dari hasil uji statistik didapat $p$-value $=0,012$ yang artinya Ha diterima atau terdapat pengaruh pengetahuan ibu terhadap pola asuh orang tua pada anak usia dini.

Hasil penelitian ini sama dengan penelitian yang dilakukan oleh Dwi ,(2009) yang Analisis Tingkat Pendidikan Dan Pola Asuh Orang Tua Dengan Perkembangan Anak Usia 48-60 Bulan" dari 60 responden yang berpengetahuan cukup hanya 20 responden $(33,3 \%)$ dengan pola asuh atoriter, dari hasil uji statistik didapat $\mathrm{p}$-value $=0,010$ yang artinya $\mathrm{Ha}$ diterima atau terdapat pengaruh pengetahuan ibu terhadap pola asuh orang tua pada anak Perkembangan Anak Usia 48-60 bulan.

Menurut Notoatmodjo, (2005) Pengetahuan merupakan hasil dari tahu, dan ini terjadi setelah orang melakukan penginderaan terhadap suatu objek tertentu. Penginderaan terjadi melalui pancaindra manusia, yakni indra penglihatan, pendengaran, penciuman, rasa dan raba. Sebagian besa pengetahuan manusia diperoleh melalui mata dan telinga.

Pengetahuan menjadi landasan penting untuk menentukan suatu tindakan. Pengetahuan, sikap dan perilaku seseorang akan kesehatan merupakan faktor yang menentukan dalam mengambil suatu keputusan. Orang yang berpengetahuan baik akan mngupayakan kemampuan menerapkan pengetahuannya di dalam kehidupan sehari-hari (Notoatmodjo, 2005).

Menurut WHO pengetahuan diperoleh dari pengalaman sendiri atau pengalaman orang lain. Jadi pengetahuan dalah hasil dari tahu. Dengan demikian atau kognitif merupakan domain yang sangat penting dalam membentuk tindakan seseorang (Overt behavior). 
Peneliti berasumsi bahwa pengetahuan sangat mempengaruhi pola asuh dialogis karena, ibu di desa batoh yang pengetahuannya tinggi sumbangan efektifnya yaitu 80,6\%. pengetahuan akan sangat berpengaruh terhadap kepercayaan seseorang, Seseorang yang memiliki pengetahuan tinggi akan semakin positif tentang hal-hal yang kebenarannya nyata.

3. Pengaruh Pendapatan Keluarga Terhadap Pola Asuh Orang Tua Pada Anak Balita

Berdasarkan hasil penelitian yang telah dilakukan oleh peneliti bahwa dari 33 responden ibu yang pendapatan keluarga yang sesuai UMP melakukan pola asuh dialogis sebesar 78,8\%. Dari 49 responden ibu yang berpendapatan keluarga yang tidak sesuai dengan UMP melakukan pola asuh dialogis sebesar 42,9\%.

Hasil analisis statistik menggunakan uji chi-square didapatkan $\mathrm{p}$ value $=0,003$. Sehingga dapat disimpulkan bahwa $\mathrm{p}<0,05$ yang artinya Ha diterima atau terdapat pengaruh pendapatan keluarga terhadap pola asuh orang tua pada anak balita di Desa Batoh Kecamatan Lueng BataKota Banda Aceh Tahun 2016.

Hasil penelitian ini sama dengan penelitian yang dilakukan oleh Amin ,2009) yang berjudul "Faktor-Faktor Yang Mempengaruhi Pengetahuan Ibu Tentang Pola Asuh Anak Balita di Posyandu Gampong Panjo Kecamatan Kembang Tanjong Kabupaten Pidie"dari 20 responden yang pendapatan keluarga tinggi hanya 10 responden (50\%) dengan pola asuh dialogis, Dari hasil uji statistik didapat $\mathrm{p}$-value $=0,001$ yang artinya $\mathrm{Ha}$ diterima atau terdapat pengaruh pendapatan terhadap pola asuh orang tua pada anak balita.

Hasil penelitian ini sama dengan penelitian yang dilakukan oleh Kharmina,(2009) yang berjudul "Hubungan Antara Tingkat Pendidikan Orang Tua Dengan Orientasi Pola Asuh Anak Usia Dini "dari 40 responden yang pendapatan keluarga tinggi sebersar 20 responden $(50 \%)$ dengan pola asuh dialogis. Dari hasil uji statistik didapat $p$-value $=0,001$ yang artinya Ha diterima atau terdapat pengaruh pendapatan keluarga ibu terhadap pola asuh orang tua pada anak usia dini.

Hasil penelitian ini sama dengan penelitian yang dilakukan oleh Ike Marlina, (2009) yang Pengaruh Pola Asuh Orang Tua Terhadap Kecerdasan Emosi Siswa Kelas V Sd Se Gugus II Kecamatan Umbulharjo Yogyakarta "dari 50 responden yang pendapatan keluarga tinggi hanya 30 responden $(60 \%)$ dengan pola asuh dialogis. Dari hasil uji 
statistik didapat $\mathrm{p}$-value $=0,01$ yang artinya $\mathrm{Ha}$ diterima atau terdapat pengaruh pendapatan keluarga ibu terhadap pola asuh orang tua dengan Kecerdasan Emosi.

Menurut Yayuk, (2007) keadaan ekonomi keluarga relatif lebih mudah diukur dan berpengaruh besar pada konsumsi pangan, dimana konsumsi pangan pada balita ditentukan dari pola asuh gizi, terutama pada keluarga golongan miskin. Hal ini disebabkan karena penduduk golongan miskin menggunkan sebagian besar pendapatanya untuk memenuhi kebutuhan makanan. Perubahan pendapatan dapat mempengaruhi perubahan pola asuh gizi yang secara langsung mempengaruhi konsumsi pangan pada balita. Meningkatnya pendapatan bearti memperbesar peluang untuk membeli pangan dengan kualitas dan kuantitas yang lebih baik. Sebaliknya penurunan pendapatan akan menyebabkan penurunan dalam hal kualitas dan penurunan kuantitas pangan yang dibeli.

Penulis berasumsi bahwa pendapatan keluarga sangat mempengaruhi pola asuh dialogis karena,ibu di desa batoh yang pendapatan keluarga nya sesuai UMPsumbangan efektifnya tinggi yaitu 78,8\%. semakin tinggi tingkat pendapatan keluarga maka akan menyebabkan peningkatan dalam hal kualitas dan kuantitas pangan yang dibeli. Hal ini disebabkan karena pendapatan keluarga yang berpengaruh terhadap daya beli keluarga juga menjadi tinggi.

\section{Pengaruh Status Gizi Terhadap Pola Asuh Orang Tua Pada Anak}

Berdasarkan hasil penelitian yang telah dilakukan oleh peneliti bahwa dari 25 responden ibu yang status gizi balitanya kurus melakukan pola asuh dialogis sebesar $80,0 \%$ dari 14 responden ibu yang status gizi anak balitanya gemuk melakukan pola asuh dialogis sebesar 50,0\%. Dari 43 responden ibu yang status gizi anak balitanya normal yang melakukan pola asuh dialogis sebesar $46,5 \%$.

Hasil analisis statistik menggunakan uji chi-square didapatkan $\mathrm{p}$ value $=0,022$. Sehingga dapat disimpulkan bahwa $\mathrm{p}<0,05$ yang artinya Ha diterima atau terdapat pengaruh status gizi terhadap pola asuh orang tua pada anak balita di Desa Batoh Kecamatan Lueng BataKota Banda Aceh Tahun 2016.

Hasil penelitian ini sama dengan penelitian yang dilakukan oleh Rosdiana,(2009) yang berjudul "Hubungan Pola Asuh dan Asupan gizi Terhadap Status Gizi Anak usia 624 Bulan Pada Daerah Pesisir Pantai di Kelurahan Mengempang Kecamatan Baru Kabupaten Pidie " dari 70 responden yang status gizi baik sebesar $65 \%$ dengan pola asuh 
dialogis Dari hasil uji statistik didapat $\mathrm{p}$-value $=0,023$ yang artinya Ha diterima atau terdapat pengaruh gizi terhadap pola asuh orang tua pada anak balita.

Hasil penelitian ini sama dengan penelitian yang dilakukan oleh Dwi ,2009) yang Analisis Tingkat Pendidikan Dan Pola Asuh Orang Tua Dengan Perkembangan Anak Usia 48-60 Bulan" dari 30 responden yang status gizi baik sebesar $85 \%$ dengan pola asuh dialogis Dari hasil uji statistik didapat $\mathrm{p}$-value= 0,009 yang artinya Ha diterima atau terdapat pengaruh gizi terhadap pola asuh orang tua Dengan Perkembangan Anak Usia 48-60 Bulan pada anak usia dini.

Hasil penelitian ini sama dengan penelitian yang dilakukan oleh Ike Marlina, (2009) yang Pengaruh Pola Asuh Orang Tua Terhadap Kecerdasan Emosi Siswa Kelas V Sd Se Gugus II Kecamatan Umbulharjo Yogyakarta "dari 60 responden yang status gizi baik sebesar $45 \%$ dengan pola asuh dialogis Dari hasil uji statistik didapat p-value $=0,01$ yang artinya Ha diterima atau terdapat pengaruh gizi terhadap pola asuh orang tua dengan Kecerdasan Emosi

Menurut Suhardjo (1986), praktek pola asuh gizi dalam rumah tangga biasanya berhubungan erat dengan factor pendapatan keluarga, tingkat pendidikan dan pengetahuan ibu. Anak -anak yang tumbuh dalam suatu keluarga tidak mampu adalah paling rawan terhadap kurang gizi diantaranya seluruh anggota keuarga lainnya dan anak kecil paling berpengaruh oleh kurang pangan untuk setiap anak berkurang dan banyak orang tua yang tidak menyadari bahwa anak-anak yang sangat muda perlu zat gizi yang relative lebih banyak dari pada anak-anak yang lebih tua.

Penulis berasumsi bahwa status gizi anak balita sangat mempengaruhipola asuh dialogis karena, ibu didesa batohyang status gizi anak balitanya kurus sumbangan efektifitasnya tinggi $80,0 \%$.gizi juga menjadi peran penting dalam kehidupan sehari-hari untuk menghasilkan anak balita yang lebih baik karena kebutuhan gizi dapat terpenuhi lewat pola makan yang baik dan sehat, tetapi dari hasil penelitian peneliti di dapatkan status gizi lebih banyak yang kurus dibandingkan dengan status gizi yang normal.

\section{KESIMPULAN}

Berdasarkan hasil penelitian yang telah dilakukan maka peneliti dapat mengumpulkan hasil dari penelitian sebagai berikut : 
1. Ada Pengaruh pendidikan ibu dengan pola asuh dialogis di Desa Batoh Kecamatan Lueng BataKota Banda Aceh Tahun 2016, didapatkan p value = 0,024

2. Ada Pengaruh pengetahuan ibu dengan pola asuh dialogis di Desa Batoh Kecamatan Lueng BataKota Banda Aceh Tahun 2016, didapatkan $\mathrm{p}$ value = 0,002.

3. Ada Pengaruh pendapatan ibu dengan pola asuh dialogis di Desa Batoh Kecamatan Lueng BataKota Banda Aceh Tahun 2016, di dapatkan $\mathrm{p}$ value = 0,003.

4. Ada Pengaruh status gizi anak balita dengan pola asuh dialogis di Desa Batoh Kecamatan Lueng BataKota Banda Aceh Tahun 2016, didapatkan p value = 0,022

\section{DAFTAR PUSTAKA}

Anwar, (2008).Pola Asuh Kebidanan, Yogyakarta Pustaka Belajar

Amal, (2007).Prilaku Pola Asuh AnakJakarta : Rineka Cipta.

Azwar, (2005).Pendidikan Kesehatan, Jakarta :Rineka Cipta.

Aural, (2005).Pola Anak,Jakarta : Rineka Cipta

Amin, (2003).Keaslian Penelitian, Jakarta : Rineka Cipta

Albertina Putuhena, (1998). Keaslian Penelitian, Jakarta : Rineka Cipta

Arikunto, (2006).Pengolahan dan Analisa Data, Jakarta : Rineka Cipta

Atmatsier, (2010).Angka Kecukupan Gizi, Jakarta : Rineka Cipta

Hidayat, (2009).Pengertian Pola Asuh,Jakarta : Rineka Cipta.

Hardinsyah, (2007). Kesehatan Gizi Anak, Jakarta : Rineka Cipta.

Nursalam, (2005). Pola Asuh Anak, Jakarta : Rineka Cipta.

Notoadmodjo, (2005). Jenis Penelitian, Jakarta : Rineka Cipta.

Notoadmodjo, (2005). Populasi dan Sampel, Jakarta : Rineka Cipta.

Notoadmodjo, (2007).Konsep Pendidikan, Jakarta : Rineka Cipta.

Nyoman, (2010).Status Gizi, Jakarta : Rineka Cipta

Rogers, (2007).Konsep Pengetahuan, Yogyakarta Penerbit Pustaka Belajar.

Sjahmien, (2011). Zat Gizi Anak Balita : Jakarta Rineka Cipta

Titih Huriah, (2003). Keaslian Penelitian, Jakarta : Rineka Cipta

Yakyuk, (2007).Konsep Pendapatan, Jakarta ; Rineka Cipta. 